\title{
THE PROTECTIVE EFFECT OF L-CARNITINE AGAINST SUBCHRONIC TOXICITY OF FORMALDEHYDE ON RABBIT'S TESTICULAR FUNCTIONS
}

\author{
$B \mathcal{B Y}$ \\ Safaa M. George, Heba A. Yassa and Hassan A. Hussein* \\ Departments of Forensic Medicine and Clinical Toxicology, Faculty of Medicine. \\ and *Theriogenology, Faculty of Vetrinary, Assiut University
}

\begin{abstract}
Formaldehyde is naturally produced in our bodies and is found in mulli products around us. This study aimed to examine the effects of formaldehyde exposure in milk upon rabbits' testicular functions and the possible protective role of L-Carnitine as an antagonist for these effects. Twenty male adult rabbits were used in the present study, divided into four groups. Control group, formaldehyde group, formaldehyde and L-Carnitine group and L-Carnitine group. Semen analysis was done for all groups in addition to Doppler Ultrasonography for testicles. All seminal parameters were affected by formaldehyde exposure in milk; the effects were severe in the form of decrease the sperm count, motility, and increase in the abnormal forms. In contrary rabbits received L-Carnitine showed dramatic improvement in all seminal parameters. Conclusion: $L$ - Carnitine can be used as a protective agent for formaldehyde effects on testicular disorders.
\end{abstract}

\section{INTRODUCTION}

Formaldehyde is produced naturally in our bodies by normal metabolism and can also be found in the air, food, some skin-care products as well as preservative in processed food, especially dried food and frozen food (Weng et al,, 2009). Homes containing large amounts of formaldehyde in pressed wood products and fiber bread. Outdoor also contains large amounts of formaldehyde which may exceed the maximum allowable concentration of the NIOSH (The National Institute of Safety and Health) which is $16 \mathrm{ppb}$. In Egypt (Cairo) this level reach $33 \mathrm{ppb}$ in 1999 (Zhang et al., 2009).

Formaldehyde is a carbonyl compounds, known for its antimicrobial activity. It is directly used as bacteriostatic in cheese and milk to prevent Closridium sp. from forming gas holes during the manufacture of cheese. Hexamethylene tetramine is a chemical compound commonly used for fruit washing. This compound breaks down to formaldehyde to give protection against microorganisms (Ogbadu, 2004). 
If the amount of formaldehyde is small, it does not harm health. However, it can cause minor to serious problems such as pain, vomiting, coma and possible death when a large amount is taken (Weng et al., 2009). It has great toxic effects on liver and testicles (Majumder and Kumar, 1995; Odeigah, 1997; Tang et al., 2003). Liver is considered the organ of metabolism in oral formaldehyde toxicity, this largely overlocked because formaldehyde is rapidly metabolized and removed and can be reduced by alcohol deydrogenase or oxidized to formate by mitochondrial dehydrogenase (Teng et al., 2001).

Health and Human Services (DHHS, 1981), the International Agency for Research on Cancer (IARC, 2004) and the US Environmental Protection Agency (EPA, 1999) have concluded that formaldehyde is probably carcinogenic to humans. Therefore, EPA set the guideline for the acceptable daily intake (ADI) of formaldehyde to $0.2 \mathrm{mg} / \mathrm{kg}$ body weight and warned the potential adverse health effects will be greater for intake of formaldehyde more than ADI.

Carnitine, (3- hydroxyl-4N- trimethylammonio-butanoate) is a naturally occurring substance found in most cells of the body, particularly the brain, neural tissues, muscles and heart. Carnitine (CA) is the generic term for a number of compounds that include L-carnitine (LC), ace-
tyl-L-carnitine (ALC), and propionyl-Lcarnitine (PLC). It is synthesized primarily in the liver and the kidneys from two amino acids, lysine and methionine. Carnitine is widely available in animal and sea foods (meat, poultry, fish and diary products), whereas plants have very small amounts. Its name was derived from (carne) which means meat in Latin and Spanish, as the compound was mainly isolated from meat (Jogl et al., 2004).

Carnitine primary mechanism of action is apparently attributable to its role as a cofactor in the transformation of free long -chain fatty acid into acylcarnitine for subsequent transport into the mitochondrial matrix (Fukao et al., 2004; Jogl et al., 2004). L- Carnitine (LC) and acetyl-l- carnitine (ALC), play several important roles in human body, practically in energy metabolism. These nutrients shuttle acetyl groups and fatty acids into mitochondria for energy production. Without carnitine (CA), fatty acids cannot easily enter into mitochondria (Rahbar et al., 2005). Makowski et al., (2009) recorded the potential value of supplemental carnitine as a therapy for several metabolic disorders. Use of carnitine showed some promise in a controlled trial in selected cases of male infertility improving sperm quality (Lenzi et al., 2003). L-Carnitine supplementation has also shown to have beneficial effects in the treatment of varicocele, a major cause of male infertility (Seo et al., 2010). 
Carnitine according to Evangeliou and Vlassopoulos (2003) is available as a supplement in variety forms:

- L-carnitine (LC): the most widely available and least expensive form.

- Acetyl-L-carnitine (ALC): often used in Alzheimer's disease and other brain disorders.

- Propionyl-L-carnitine (PLC): often used in heart and peripheral vascular diseases.

\section{AIM OF THE STUDY}

This study was designed to evaluate the possible protective effect of L-Carnitine on testicular functions after formaldehyde subchronic toxicity in rabbits.

\section{MATERIAL AND METHOD}

\section{Animals:}

Twenty sexually mature mixed breed males and two female rabbits (aged between 12 and 14 weeks) weighing $2.15 \pm 0.32 \mathrm{~kg}$ were used. Animals were obtained from the Animal House of Faculty of Medicine, Assiut University. They were individually housed in cages in the experimental animal house, under natural climatic condition (temperature range, 1525C) with free access to food and water. Animals were fed ad libitum with commercial rabbit pellets (protein 15\%, lipid $2.9 \%$ and fiber $12.30 \%$ ). Food consumption and animals' weight were measured weekly throughout the experimental period. Females were used as teaser for semen col- lection from the males. For acclimation of the male rabbits and during the first month, trails for semen collection using artificial vagina were done twice per week, for rabbits training to collect semen.

\section{Experimental design :}

In the following month, the twenty rabbit males were divided equally and randomly into four groups ( $n=5$ for each). A control group (group I) was received saline, (group II) was received market milk for 3 months as a subchronic study (Makowski et al., 2009) after estimation of the level of formaldehyde by HPLC (High performance liquid chromatography) which was $0.5 \mathrm{gm} / \mathrm{L}$ (concentration was $0.09 \mathrm{mg} / \mathrm{Kg}$ ) and this level is above the al lowed level which should be less than 0.02 $\mathrm{mg} / \mathrm{Kg}$, (group III) was received LCarnitine orally for three monthsin a dose of $250 \mathrm{mg} / \mathrm{kg}$ according to (Stvolinsky and Dobrota, 2000) and (group IV) was received the L-Carnitine a dose of $250 \mathrm{mg} /$ $\mathrm{kg}$ for the same period. Through the experimental duration, animals were observed for weight or any developed diseases. Testicular ultrasonography and semen analysis were done for all groups.

\section{High performance liquid chromatogra- phy (HPLC):}

Twenty types of milk in the market were studied and analyzed to detect the amount of formaldehyde in them by HPLC. 
According to Kaminski et al. (1993) and $\mathrm{Li}$ et al. (2007), HPLC system (Agilent Technologies, USA) has a VU detector, its column was a Hypersil ODS2$\mathrm{C} 18,5 \mu \mathrm{m}, 200 \mathrm{~mm} \times 4.6 \mathrm{~mm}$. The absorbed wavelength of detector was set at $355 \mathrm{~nm}$. The mobile phase was meth anol-water $(60: 40, v / v)$ with a flow rate of $1 \mathrm{ml} / \mathrm{min}$. The peak area was used for quantitative calculation of formaldehyde.

\section{Milk preparation for HPLC:}

According to Kaminski et al. (1993), milk preparation for HPLC analysis is done by addition of acidified DNPH $(2,4$ dinitrophenylhydrazine) and hexane to 2 $\mathrm{mL}$ of milk sample, stirring for 30 minutes at room temperature, filtration through Celite, washing with hexane, evaporation of solvent and finally redissolution in acetonitrile.

\section{Calibration curve :}

According to $\mathrm{Li}$ et al. (2007), the formaldehyde powder was diluted from $20 \mathrm{mg} / \mathrm{L}$ of formaldehyde stock solution, containing $0,2,5,10,15,20 \mathrm{mg} / \mathrm{L}$ formaldehyde respectively. A $1 \mathrm{~mL}$ volume of each formaldehyde solution was derivatized and extracted. Three injections of each standard solution were made and the peak area was the corresponding formaldehyde concentration to obtain the calibration curve.
Ejaculates collection and gross sperm evaluation:

The artificial vagina (AV) for semen collection was directly connected with a graduated collector tube and filled with warm water $(60 \mu \mathrm{C})$. The AV was always used when inner temperatures fell between 45 and $50 \mu \mathrm{C}$ (Andrade et al., 2002; Naughton et al., 2003). Before semen collection, bucks were allowed one false mount and at the subsequent mounting, the AV was adequately positioned between the female hindquarters for penis intromission. Bucks have been previously adapted to this routine and no refusals occurred. In all animals, ejaculates were collected once weekly on Monday morning. The experiment was carried out for a period of 3 months from the last week of October to the last week of January. Before starting the experiment, animals producing ejaculates containing urine and calcium carbonate deposits were discarded. The color, $\mathrm{pH}$ using pH-paper and volume (V) of the ejaculate was determined using a graduated conical plastic tube. Gel plugs, when present, were removed before volume evaluation. Drops of the ejaculates were primarily diluted (1:5) in a buffer phosphate extender and evaluated for sperm motility and subsequently shipped to the laboratory of theriogenology of the veterinary medicine within $1 \mathrm{~h}$ for further sperm evaluation. 


\section{Evaluation of sperm quality :}

Evaluation of spermatozoa quality included sperm motility, morphology, viability and acrosome integrity. Before the evaluation, semen was diluted (1:8 ratio) in a Trisbuffered extender (Roca et al., 2000) and incubated for $30 \mathrm{~min}$ in a warm water bath at $30^{\circ} \mathrm{C}$. The percentage of motile spermatozoa (SMOT) were evaluated from three samples of the diluted spermatozoa placed under a cover slide in the centre of a pre-warmed $\left(37^{\circ} \mathrm{C}\right)$ slide and transferred to a heated microscope stage set at $37^{\circ} \mathrm{C}$. The evaluation was subjectively assessed using phase contrast microscopy (X200 magnification, Leica, Germany). The SMOT was recorded on a five multiple scale of 0 to 5 where 0 is absence of movement and 5 is progressive motility of all spermatozoa. The proportions of spermatozoa with abnormal morphology ( $\mathrm{SAB}$ ) and acrosomal integxity (ACIN) were measured by staining slides with Giemsa's stain and examined under a phase contrast microscope at the magnification of 1000 X. Morphologic abnormalities included head, midpiece (excluding distal cytoplasmic droplets) and tail defects. The viable sperm percent (VSP) was determined using eiosin-Nigrosin stain. Two hundred spermatozoa were counted from each preparation of $\mathrm{SAB}, \mathrm{ACIN}$ and VSP. Sperm concentration was evaluated in a haemocytometer after extending $(1: 400, v / v)$ an aliquot of semen with $0.3 \%$ formaldehyde in phosphate-buffered sa- line. The number of total spermatozoa per ejaculate was calculated multiplying semen volume by sperm concentration.

\section{Statistical analysis :}

Values were presented as means \pm standard deviation (S.D.). Data were analyzed by analysis of variance (SPSS version 16.0).

\section{RESULTS}

The rabbit weights were measured every week all over the study period which was 3 months ( 90 days; subchronic study), and the weight of each group were compared. Table (1), (2) and figure (1) showed the differences in weight between different groups of animals through the study. There was great statistically difference between weights of rabbits especially the group administered market milk with formaldehyde (group II) in comparison to the control group (group I). The weight returned to normal when administered with L-Carnitine with market milk (group III).

All seminal parameters were measured in the four groups and compared with each others in table (3). This table showed that all seminal parameters were affected by formaldehyde in market milk (group II) and exaggerated with increasing the period of administration. The affection in seminal parameters included decreased libido, increased the alkalinity of 
the seminal fluid, decreased numbers of live sperm, decreased the motility, decreased the spermatogenic cells and increased the abnormal form. Figure (2) showed the effect of formaldehyde in market milk (group II) on the sperm motility, which revealed severe affection in comparison with the other groups, and returned to normal when the formaldehyde in market milk combined with L-Carnitine administration (group III).

Figure (3) showed the sonographic appearance of testicles at the end of the study. This figure showed increased blood vessels in the group of market milk containing formaldehyde administration (group II) in addition to decreased the size of the testicles and these effects returned to nearly normal when LCarnitine added to the formaldehyde in milk (group II).

\section{DISCUSSION}

The present study revealed the subchronic effects of formaldehyde used in milk as a preservative on testicular functions and the role of L-Carnitine as a protective to these effects.

The formaldehyde effects appear to be grave on the weight of the rabbits along the study period if compared the control group (group I) and group of formaldehyde with the L-Camitine as protective (group III). This appeared in table (1), (2) and figure (1). Grazuleviciene (1998) in his study summarized the effects of formaldehyde exposure. As he found that formaldehyde pollutants exposure had a statistically significant reduction on birth weight. Depression, dullness and anorexia were apparent in quails fed $20 \mathrm{~mL}$ formalin $/ \mathrm{kg}$ feed.

Food intake, body weight, egg production and egg weight together with absolute and relative weight of organs were decreased according to khan et al. (2005). In a study done by Kamata et al. (1997), they found significant decrease in food consumption, body weight and survival rate in animals exposed to formaldehyde. They explained these findings due to decreased triglyceride levels and absolute liver weight, in addition to decrease the food consumption.

In the present study, all semen parameters were affected by administration of formaldehyde in milk (group II) including count, motility, increased abnormal forms, $\mathrm{pH}$ and even libido were affected. On contrast, the seminal parameters return to nearly normal values with addition of L-Carnitine to the milk which contains the formaldehyde (group III). This means that L-Carnitine is a good protective for formaldehyde effects on semen analysis. 
In agreement with the present results Odeigah (1997) as he found that there was a significant increase in sperm head abnormalities in formaldehyde treated rats. Although formaldehyde is known to produce DNA protein cross-links in a cell, the precise mechanism by which formaldehyde causes sperm head abnormalities is not yet fully established. In general, damage to the sperm cell by substances may occur by physiological, cy totoxic or genetic mechanisms. In addition there are 2 mechanisms by which chemicals might indirectly affect sperm cell function and morphology: firstly, exposure to chemicals could produce pituitary-hypothalamic or sex hormonal effects which in turn could affect spermatogenesis and secondly exposure could cause abnormalities in seminal fluid, resulting in functional or structural impairment of sperm.

Zhoua et al. (2011) proved that the formaldehyde affects the sperm count and motility, in addition to decrease the activities of superoxide dismutase and glutathione peroxidase. Zhou et al. (2006) also proved the harmful effects of formaldehyde on spermatogenesis as it induced atrophy of seminiferous tubules with a decrease in sperm density and an increase in abnormal sperm forms at a dose-dependent manner.

In the present study, Doppler on testicles of group II revealed that there were increased venous blood in testicles, with tortuous veins, and decreased the size of testicles. These effects were completely absent in rabbits administered L-Carnitine in milk in addition to the formaldehyde (group III). This may explain the effect of formaldehyde administration on seminal parameters.

Chowdhury et al. (1992) in their study found that there was a steady decline in body weight and testicular weight with formaldehyde administration. Ozen et al. (2002) found that subacute and subchronic formaldehyde exposure can cause growth retardation and altered levels of trace elements including copper, zinc and iron and on testicular tissue may induce oxidative damage leading to spermatozoa abnormalities.

This study was the first one that examines the effects of L-Carnitine as an antioxidant upon the effects of formaldehyde exposure in food as milk. LCarnitine administration led to marked improvement of all testicular effects induced by formaldehyde exposure. Effects of L-Carnitine as antioxidant are well studied especially on testicular functions but no other researches studied its role against formaldehyde effects. Kanter et al. (2010) found that LCarnitine attenuated the radiation induced morphological changes and germ cell apoptosis in the irradiated rat testi- 
cles. Wetterauer and Heite (1980) proved that carnitine estimation in human semen is of diagnostic value for epididymal function. About $95 \%$ of the free carnitine originates from the epididymis in normospermic persons. The clinical significance of carnitine determination is demonstrated in azoospermia, varicocele, and obstructive azoospermia. In order to obtain a general picture of the function of all the glands contributing to the formation and composition of seminal plasma we ought not to rely only on fructose estimations but should also take into account those of the citrate and carnitine.

\section{CONCLUSION}

One of the most abundant toxins in our environment is formaldehyde, which used as a preservative in many foods especially milk and dried food. Many of the hazards of formaldehyde are dose dependent and can be minimized if the dose of formaldehyde in food is adjusted. Although the toxic effects of formaldehyde on testicular functions and semen analysis were documented but L-Camitine could reverse these effects in a dramatic way. SO, LCarnitine could be a good antagonism to the toxic effects of formaldehyde on testicular functions. 
Table (1): Mean weight of the rabbits in studied groups.

\begin{tabular}{|c|c|c|c|c|c|c|}
\hline $\begin{array}{c}\text { Each } \\
\text { group } \\
\text { (no. 5) }\end{array}$ & $\begin{array}{c}\text { Weight in } \\
\text { (gm) at the } \\
\text { beginning } \\
\text { of the test }\end{array}$ & $\begin{array}{c}\text { Weight } \\
\text { after 2 } \\
\text { weeks }\end{array}$ & $\begin{array}{c}\text { Weight } \\
\text { after 4 } \\
\text { weeks }\end{array}$ & $\begin{array}{c}\text { Weight } \\
\text { after 6 } \\
\text { weeks }\end{array}$ & $\begin{array}{c}\text { Weight } \\
\text { after 9 } \\
\text { weeks }\end{array}$ & $\begin{array}{c}\text { Weight } \\
\text { after 12 } \\
\text { weeks }\end{array}$ \\
\hline Group I & 2300 & 2533 & 2633 & 2750 & 2800 & 2900 \\
\hline Group II & 2575 & 2600 & 2650 & 2653 & 2674 & 2680 \\
\hline Group III & 2400 & 2500 & 2650 & 2800 & 2913 & 2950 \\
\hline Group IV & 2400 & 2575 & 2686 & 2894 & 3000 & 3125 \\
\hline
\end{tabular}

Table (2): Paired $t$ test to compare weight in different groups.

\begin{tabular}{|c|c|c|c|}
\hline Paired $\mathrm{t}$ - test & No. & T - test & P value \\
\hline Group I - Group II & 5 per group & 0.966 & $0.002^{* *}$ \\
\hline Group II - Group III & 5 per group & 0.969 & $0.001^{* *}$ \\
\hline
\end{tabular}

Group I: control group

Group II: formaldchyde in milk

Group II: fonmaldehyde in miłk + L-Carnitine

Group IV: L-Carnitine only

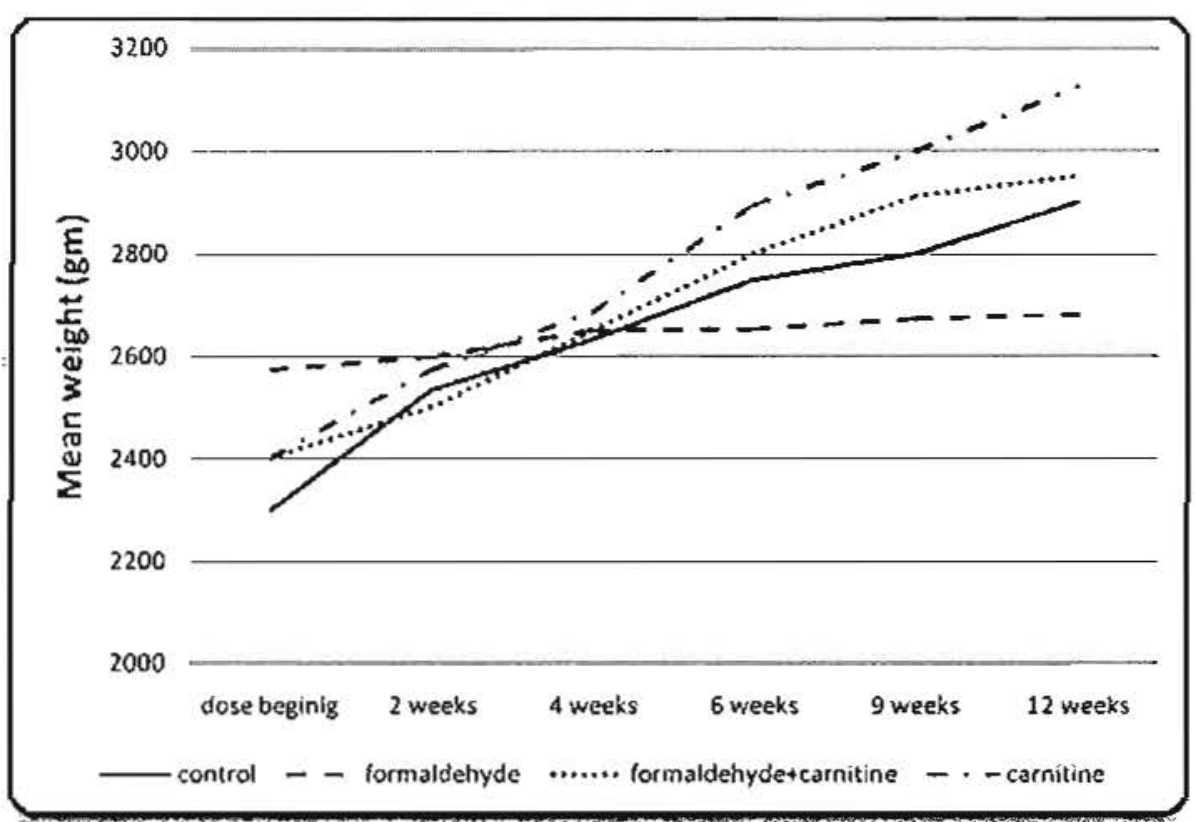

Figure (1): Mean weight of the different groups over the period of the study 
Table (3): Scminal parameters of different groups over the study period.

\begin{tabular}{|c|c|c|c|c|c|}
\hline Period & $\begin{array}{c}\text { Seminal } \\
\text { parameters }\end{array}$ & Control & $\begin{array}{c}\text { Group II } \\
\text { (Formaldchyde) }\end{array}$ & $\begin{array}{c}\text { Group III } \\
\text { Formaldehyde+ } \\
\text { Carnitine }\end{array}$ & $\begin{array}{l}\text { Group IV } \\
\text { Carnitine }\end{array}$ \\
\hline \multirow{10}{*}{ 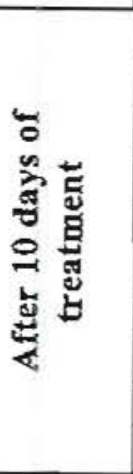 } & RT $^{*}$ & $30 \mathrm{sec}$ & $30 \mathrm{sec}$ & $30 \mathrm{sec}$ & $30 \mathrm{sec}$ \\
\hline & \begin{tabular}{|l|} 
Libido \\
\end{tabular} & Good & Good & Good & Good \\
\hline & Volume & 0.3 & $0 . \overline{3}$ & 0.2 & $0.3 \mathrm{ml}$ \\
\hline & PH & 7.2 & 7.6 & 7.0 & 7.1 \\
\hline & $\%$ Alive & 85 & 60 & 80 & 85 \\
\hline & $\%$ Dead & 15 & 40 & 20 & 15 \\
\hline & Motility & $80 \pm 1.2$ & $20 \pm \overline{1.0}$ & $75 \pm 1.23$ & $75 \pm 0.9$ \\
\hline & $\%$ Abnormal form & $5 \pm 1.02$ & $40 \pm 0.8$ & $27 \pm 0.7 \overline{8}$ & $10 \pm 0.9$ \\
\hline & $\%$ Intact & $90^{-}$ & 60 & $\overline{85}$ & 90 \\
\hline & Spermatogenic cells & 0.80 & $0 . \overline{55}$ & 0.86 & 0.79 \\
\hline \multirow{10}{*}{ 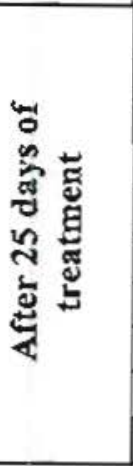 } & $\mathrm{RT}^{*}$ & $30 \mathrm{sec}$ & $90 \overline{\mathrm{sec}}$ & $30 \mathrm{sec}$ & $20 \mathrm{sec}$ \\
\hline & Libido & Very good & Fair & Very good & Very good \\
\hline & Volume & 0.5 & 0.3 & 0.2 & 0.4 \\
\hline & $\mathrm{PH}$ & 7.8 & 8.3 & 7.5 & 7.8 \\
\hline & \%Alive & 80 & 40 & 75 & 85 \\
\hline & $\%$ Dead & 20 & $\overline{60}$ & 25 & 15 \\
\hline & Motility & $80 \pm 1.0$ & $40 \pm 0.5$ & $70 \pm 0.65$ & $80 \pm 0.7$ \\
\hline & \%Abnormal form & $15 \pm 0.78$ & $40 \pm 0.5$ & $35 \pm 0.6$ & $15 \pm 0.9$ \\
\hline & $\%$ Intact & 95 & $\overline{65}$ & 80 & 80 \\
\hline & Spermatogenic cells & 0.67 & 0.55 & $0 . \overline{85}$ & 0.64 \\
\hline \multirow{10}{*}{ 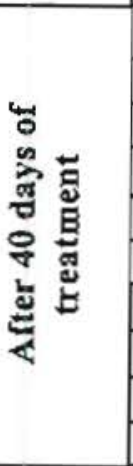 } & $\mathrm{RT}^{*}$ & $20 \mathrm{sec}$ & $90 \mathrm{sec}$ & $30 \mathrm{sec}$ & $30 \mathrm{sec}$ \\
\hline & Libido & Very good & Fair & Very good & Very good \\
\hline & \begin{tabular}{|l} 
Volume \\
\end{tabular} & 0.3 & 0.1 & 0.3 & 0.6 \\
\hline & $\mathrm{PH}$ & 7.6 & 8.5 & 7.4 & 7.8 \\
\hline & $\%$ Alive & 80 & 50 & 75 & 80 \\
\hline & $\%$ Dead & 20 & 50 & 25 & 20 \\
\hline & Motility & $80 \pm 0.7$ & $40 \pm 0.8$ & $75 \pm 0.5 \overline{4}$ & $80 \pm 0 . \overline{55}$ \\
\hline & $\%$ Abnormal form & $20 \pm 1.2$ & $35 \pm 0.7$ & $25 \pm 0.6$ & $25 \pm 0.5$ \\
\hline & $\%$ Intact & 90 & $70-$ & 90 & 80 \\
\hline & Spermatogenic cells & 0.51 & $0 . \overline{65}$ & 0.63 & 0.75 \\
\hline \multirow{10}{*}{ 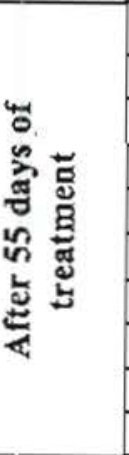 } & $\mathrm{RT}^{*}$ & $30 \mathrm{sec}$ & $10 \mathrm{sec}$ & $20 \mathrm{sec}$ & $15 \mathrm{sec}$ \\
\hline & Libido & Very good & Fair & Very good & Very good \\
\hline & Volume & 0.3 & 0.3 & 0.4 & 0.5 \\
\hline & PH & 7.2 & 8 & 7.4 & 7.4 \\
\hline & $\%$ Alive & 85 & 50 & 80 & 85 \\
\hline & $\%$ Dead & 15 & 50 & 20 & 15 \\
\hline & Motility & 80 & $\overline{40}$ & 85 & 90 \\
\hline & \%Abnormal form & 15 & 30 & 20 & 10 \\
\hline & $\%$ Intact & 85 & 70 & 80 & 90 \\
\hline & Spermatogenic cells & 0.6 & 0.4 & 0.7 & $0 . \overline{7}$ \\
\hline
\end{tabular}




\begin{tabular}{|c|c|c|c|c|c|}
\hline Period & $\begin{array}{c}\text { Seminal } \\
\text { parameters }\end{array}$ & Control & $\begin{array}{c}\text { Group I } \\
\text { (Formaldehyde) }\end{array}$ & $\begin{array}{c}\text { Group II } \\
\text { Formaldehydet } \\
\text { Carnftine }\end{array}$ & $\begin{array}{l}\text { Group III } \\
\text { Carnitine }\end{array}$ \\
\hline \multirow{10}{*}{ 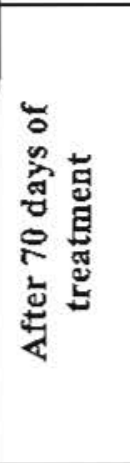 } & $\mathrm{RT}^{*}$ & $30 \mathrm{sec}$ & $30 \mathrm{sec}$ & $30 \mathrm{sec}$ & $30 \mathrm{sec}$ \\
\hline & Libido & Good & fair & Very Good & Very Good \\
\hline & Volume & 0.4 & 0.3 & 0.3 & $0.5 \mathrm{ml}$ \\
\hline & $\mathbf{P H}$ & 7.0 & 8 & 7.1 & $7 . \overline{2}$ \\
\hline & $\%$ Alive & 85 & 40 & 80 & 80 \\
\hline & $\%$ Dead & 15 & 60 & 20 & 20 \\
\hline & Motility & $80 \pm 0.1$ & $30 \pm 1.2$ & $75 \pm 0.66$ & $75 \pm 0.8$ \\
\hline & $\%$ Abnormal form & $5 \pm 0.6$ & $60 \pm 0.3$ & $27 \pm 0.7$ & $10 \pm 0.9$ \\
\hline & $\%$ Intact & 90 & 40 & 85 & 90 \\
\hline & Spermatogenic cells & 0.80 & 0.5 & 0.86 & 0.7 \\
\hline \multirow{10}{*}{ 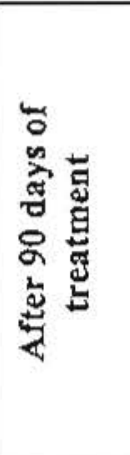 } & $\mathrm{RT}^{*}$ & $20 \mathrm{sec}$ & $90 \mathrm{sec}$ & $30 \mathrm{sec}$ & $30 \mathrm{sec}$ \\
\hline & Libido & Very good & Fair & Very good & Very good \\
\hline & Volume & 0.4 & 0.3 & 0.2 & 0.3 \\
\hline & PH & 7.5 & $8 . \overline{3}$ & 7.5 & 7.5 \\
\hline & $\%$ Alive & 80 & 40 & 75 & 80 \\
\hline & \%Dead & 20 & 60 & 25 & 20 \\
\hline & Motility & $80 \pm 0.9$ & $40 \pm 1.0$ & $70 \pm 0.56$ & $80 \pm 0.7$ \\
\hline & \%Abnormal form & $15 \pm 0.8$ & $40 \pm 1.1$ & $35 \pm 1.1$ & $15 \pm 0.8$ \\
\hline & $\%$ Intact & 95 & 65 & 80 & 80 \\
\hline & Spermatogenic cells & 0.67 & 0.55 & 0.85 & 0.64 \\
\hline
\end{tabular}

$\mathrm{RT}^{*}=$ reaction time for ejaculation

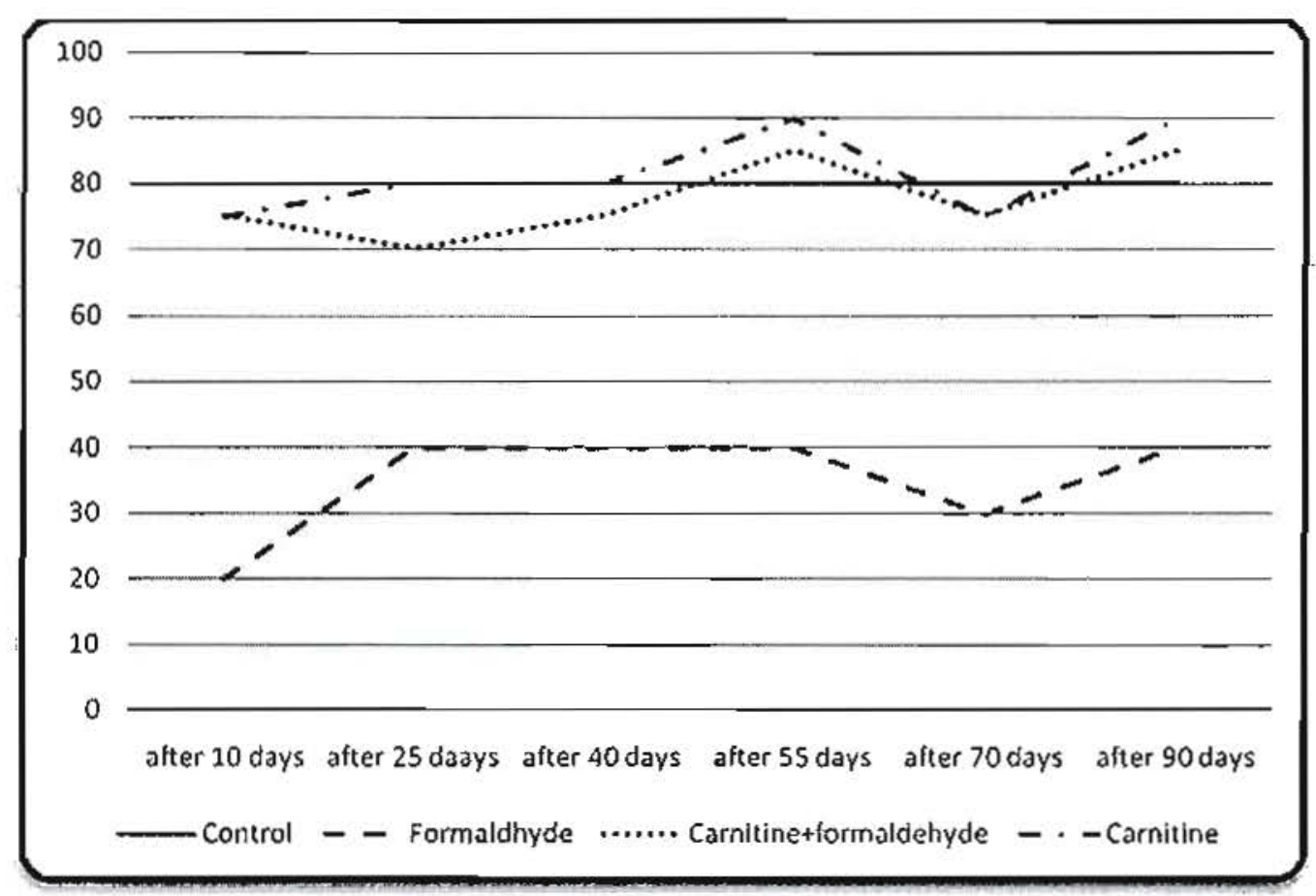

Figure (2): Sperm motility over the study period. 
Sonogrâphic results:

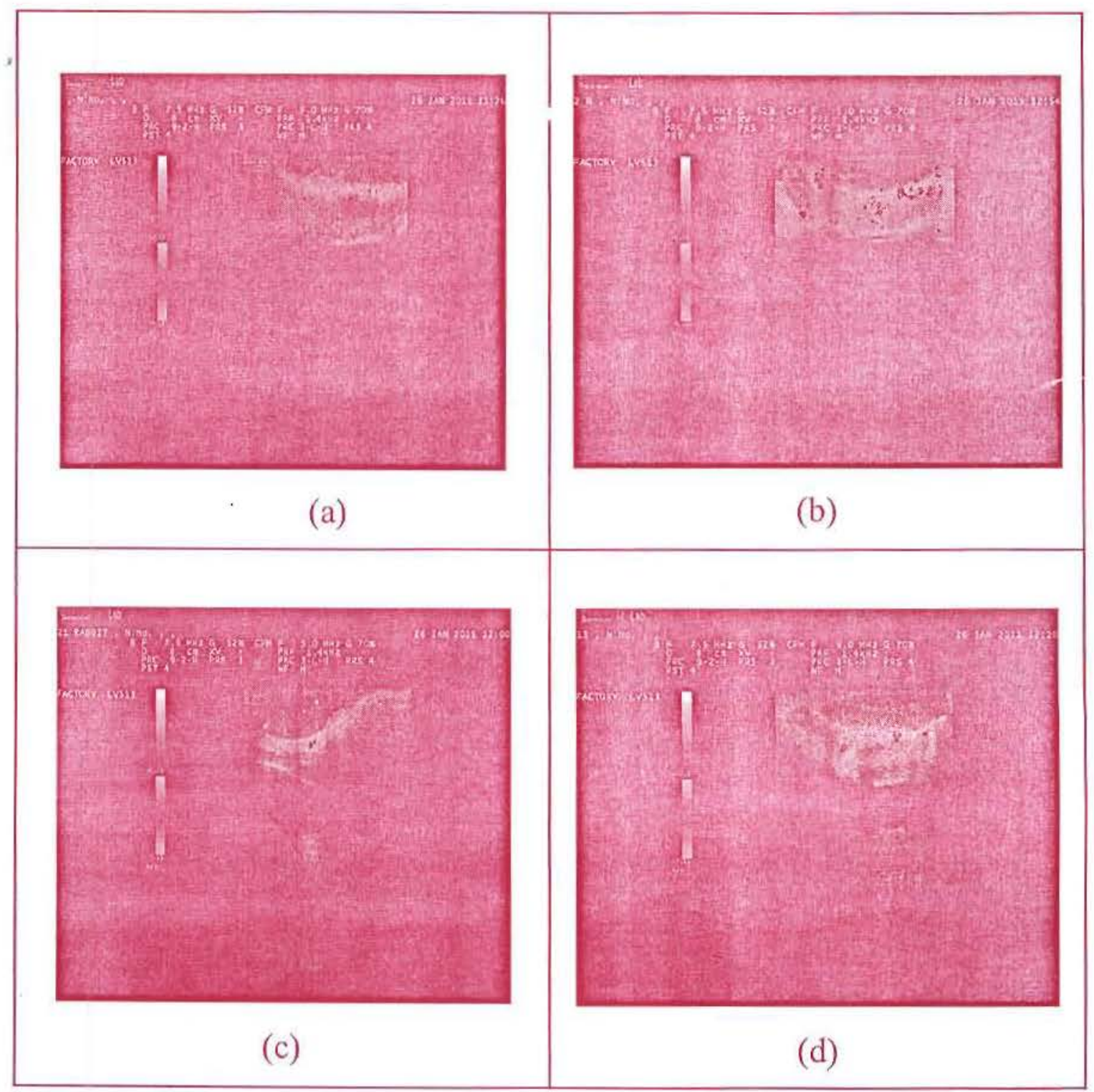

Figure (3): Sonographic results of different groups at the end of the study, (a) control group, normal sized testicle with normal blood supply (b) group $\Pi$, formaldehyde in milk, decreased testicular size with increased and dilated blood vessels(c) Group IL, formaldehyde in milk in addition to LCarnitine, testicles with normal blood supply and normal size (d) Group IV, L-Carnitine only, normal sized testicles and normal blood supply. 


\section{REFERENCES}

Andrade, A.; Yonezawa, L.; Celeghini, E.; Spers, A. and Arruda, R. (2002): “Um novo modelo de vagina artificial para coelhos". Rev. Bras. Reprod. Anim., 26:201204.

Chowdhury, A.; Gautam, A.; Patel, K. and Trivedi, H. (1992): "Steroidogenic inhibition in testicular tissue of formaldehyde exposed rats". Indian J. Physiol. Pharmacol., 36(3): 162-8.

DHHS (1981) : Formaldehyde evidence of carcinogenicity. Washington, DC: Public Health Services, National Toxicology Program.

EPA (1999) : Integrated risk information system (IRIS) on formaldehyde. Washington, DC: National Center for Environmental Assessment, Office of Research and Development".

Evangeliou, A. and Valssopoulos, D. (2003) : "Carnitine metabolism and deficit-when supplementation is necessary?" Curr. Pharm. Biotechnol., 4 : 211219.

Fukao, T.; Lopaschuk, D. and Mitchell, A. (2004) : "Pathways and control of ketone body metabolism: on the fringe of lipid biochemistry". Prostaglandins Leukot. Essent. Fatty Acids, 70:243-251.
Grazuleviciene, R. (1998) : "Formaldehyde exposure and low birth weight incidence". J. Occup. Health,4: 161-167

IARC. (2004): "Monographs on the evaluation of carcinogenic risks to humans" (Vol. 88). Lyon, France: International Agency for Research on Cancer.

Jogl, G.; Hsiao, S. and Tong, L. (2004) : "Structure and function of carnitine acyltransferases". Ann. N.Y. Acad. Sci., 1033:17-29.

Kamata, E.; Nakadate, M.; Uchida, O.; Ogawa, Y.; Suzuki, S.; Kaneko, T.; Saito, M. and Kurokawa, Y. (1997) : "Results of a 28-month chronic inhalation toxicity study of formaldehyde in male Fisher-344 rats". J. Toxicol. Sci., 22(3):239-254.

Kaminski, J.; Atwal, A. and Mahadevan, S. (1993) : "Determination of formal dehyde in fresh and retail milk by liquid column chromatography". J. of the Association of Official Analytical Chemists International, 76(5):1010-1013.

Kanter, M.; Topcu-Tarladacalisir, Y. and Parlar, S. (2010) : "Antiapoptotic effect of L-carnitine on testicular irradiation in rats". J. Mol. Histol., 6(2-3):121-128.

Khan, A.; Bachaya, H.; Khan, M. and Mahmood, F. (2005) : "Pathological effects of formalin ( $37 \%$ formaldehyde) feeding 
in female Japanese quails (Coturnix coturnix japonica)". Human \& Experimental Toxicology, 24: 415-422

Lenzi, A.; Lombardo, F.; Sgro, P.; Salacone, P.; Caponecchia, L.; Dondero, F. and Gandini, L. (2003) : "Use of carnitine therapy in selected cases of male factor infertility: a double-blind crossover trial." Fertility and Sterility, 79(2): 292 - 300

Li, J.; Zhu, J. and Xe, L. (2007) : "Determination of formaldehyde in squid by high performance liquid chromatography". Asia Pac. J. Clin. Nutr., 16 (S. 1):127130

Majumder, P. and Kumar, V. (1995) : "Inhibitory effects of formaldehyde on reproductive system of male rats". Indian journal physiology and pharmacology, 39 (1): $80-82$.

Makowski, L.; Noland, R.; Koves, T. et al. (2009) : "Metabolic profiling of PPARY mice reveals defect in carintine and amino acid homeostasis that are partially reversed by oral carnitine supplementation". The FASEB journal, 23:586-604.

Naughton, C.; Nelson, D. and Thomas, J.; (2003) : "Development of an inexpensive artificial vagina for semen collection from rabbits". Journal of Andrology, 24 (5): 712-715.
Odeigah, P. (1997) : "Sperm head abnormalities and dominant lethal effects of formaldehyde in albinorats". Mutation Research/Genetic Toxicology and Environmental Mutagenesis, 389(2-3): 141-148.

Ogbadu, L. (2004) : "Preservatives / traditional preservatives". Encyclopedia of Food Microbiology, 1737 - 1743.

Ozen, O.; Yaman, M.; Sarsilmaz, M.; Songur, A. and Kus, I. (2002) : "Testicular zinc, copper and iron concentrations in male rats exposed to subacute and subchronic formaldehyde gas inhalation". J. of Trace Elements in Medicine and Biology, 16 (2): 119-122.

Rahbar, R.; Shakerhosseini, R.; Saadat, N.; et al. (2005) : "Effect of L-carnitine on plasma glycemic and lipidemic profile in patients with type II diabetes mellitus". Eur. J. Cin. Nutr., 2:16-22.

Roca, J.; Martinez, S.; Vazquez, J.; Lucas, X. and Martinez, E. (2000) : "Viability and fertility of rabbit spermatozoa diluted in Trisbuffer extenders and stored at 15 $8 C^{\prime \prime}$. Anim. Reprod. Sci., 64: 103-112.

Seo, J.; Kim, K.; Moon, M. and Kim, W. (2010) : "The significance of microsurgical varicocelectomy in the treatment of subclinical varicocele". Fertil. Steril., 93 (6): 1907-1910. 
Stvolinsky, S. and Dobrota, D. (2000) : "Anti-ischemic activity of carnosine". Biochemistry (Moscow), 65: 849-855.

Tang, M.; Xie, Y.; Yi, Y. and Wang, W. (2003) : "Effects of formaldehyde on germ cells of male mice". Weisheng Yanjiu Nov., 32(6):544 - 548.

Teng, S.; Beard, K.; Pourahamad, J.; Moridani, M.; Easson, E.; Poon R. and Obrien, P. (2001) : "The formaldehyde metabolic detoxification enzymes systems and moleculer cytotoxic mechanism on isolated rat hepatocytes". Chemico Biological Interactions, 130 : $285-296$.

Weng, $X_{\text {; }}$ Chon, $C$; Jiang, $H$. and Li, D. (2009) : "Rapid detection of formaldehyde concentration in food on a polydimethylsiloxane (PDMS) microfluidic chip". Food Chemistry, 114: 1079-1082.
Wetterauer, U. and Heite, H. (1980) : "Carnitine in Seminal Plasma: its significance in diagnostic andrology". Informa. Health Care, 4 (2): 137-143.

Zhang, L.; Steinmaus, C.; Eastmond, D.; Xin, X. and Smith, M. (2009) : "Formaldehyde exposure and leukemia: a new meta analysis and potential mechanisms". Mutation research, 681(2-3): 150- 168.

Zhou, D.; Qiu, S.; Zhang, Z. and Wang, H. (2006) : "Effect of formaldehyde on spermatogenesis and testicular morphology in adult rats". Journal of US -China Medical Science, 3(3): 57-60

Zhoua, D.; Zhang, J.; Wang, H. and Xue, Y. (2011) : "Effect of formaldehyde exposure on structure and function of epididymis in adult rats: a histological and biochemical study". Toxicological and Environmental Chemistry, 93(1): 134 - 144. 


\section{الدور الوقائي للكارنيتين علي وظائذ الخصية في حالات التسهمم

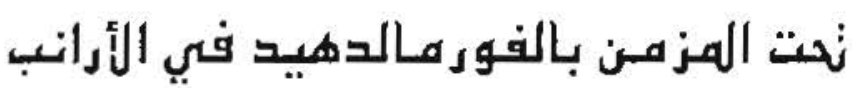

$$
\text { الشتركن فى البحث }
$$

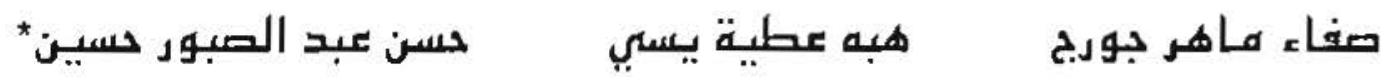 من تسمى الطب الشرعي والسوم الإكلينيكية كلية الطب - * تسم التناسلبات كلية الطب البيطرى - جأمسن أسيوط}

ينتج الفورمالدهيد طبيعيا في أجسامنا ويوجد في منتجات عديدة حولنا. تهدف هذه الدراسة إلي فحص تأثبرات التعرض للفورمالدهيد علي وظلنف المتصبة في الأرانب والدور الوتاني للكارنيتين كضاد لهذه التأثيرات. أجريت هذه الدراسة لمدة نلاثة شهرر علي .ب من ذكور الأرانب الببالغة وتد تسعت إلي أريعة مجموعات (خمسة أرانب لكل مجسوعة) . المجموعة الأرلي (المجـوعة الضابطة) ، المجموعة الثـانبة

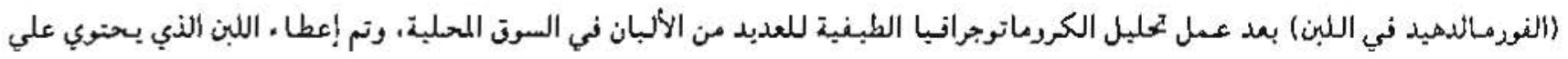
نسبة من الفورمالدهيد أعلي من المسموح به محليا. المجموعة الثالثة (الفورمالدهيد بالإضافة الي الكارنيتين) . المجموعة الرابعة (الكارنيتين)؛ وتم متابعة وزن الأرانب وعمل التحلبل للساثل المنوي وأشعة تلفزبونية للخصبة دوريا. أظهرت ألنتائج أن كل تيأسات السانل المنوي تد تأثرت نتيجة تناول الفورمالدهيد ني اللبن اني صورة نقصان لعدد الحبيوانات المنوية وتلة الحركة رأرتفاع نسبة الاشكال الشاذة، بالإضانة إلي نتصان شديد بالوزن وتغبرات بالأشعنة التلفزيونبة علي خصي الأرانب وتد تحسنت بشكل ملحوظ مع تنارل الكارنيتين. وقد خلصن الدراسة الي أثه من المكن استخدام الكارنيتين للوتاية من التأثيرات الضارة الفورمالنهيد علي المنصية. 